Original Research Paper

\title{
Effects of Salt Stress on Ion Balance at Vegetative Stage in Rice (Oryza sativa L.)
}

\author{
${ }^{1}$ Kirill V. Azarin, ${ }^{2}$ Andrey V. Alabushev, ${ }^{1}$ Alexander V. Usatov, \\ ${ }^{2}$ Pavel I. Kostylev, ${ }^{1}$ Natalia S. Kolokolova and ${ }^{1}$ Olga A. Usatova \\ ${ }^{I}$ Southern Federal University, Rostov-on-Don, Russia \\ ${ }^{2}$ All-Russian Research Institute of Grain Crops after I.G. Kalinenko, Zernograd, Russia
}

Article history

Received: 18-11-2015

Revised: 11-03-2016

Accepted: 16-03-2016

Corresponding Author:

Kirill V. Azarin

Southern Federal University,

Rostov-on-Don, Russia

Email: azkir@rambler.ru

\begin{abstract}
Rice (Oryza sativa L.) plants were subjected to $\mathrm{NaCl}$ stress within 35 days. The shoot dry weight, root dry weight, total survival percentage and contents of inorganic ions in dry samples of stressed plants were measured to identify the physiological adaptive mechanisms by which rice plants at vegetative stage tolerate salt stresses. Laboratory testing of the 10 rice cultivars showed that the salt concentration for the treatment is especially significant for assessment of the relationship between ion accumulation and salt tolerance. Salt treatment strongly stimulated accumulations of $\mathrm{Na}^{+}, \mathrm{Na}^{+} / \mathrm{K}^{+}$ratio, $\mathrm{Cl}^{-}$in shoot and root and reduced $\mathrm{K}^{+}, \mathrm{NO}_{3}^{-}$contents in both organs under $1.2 \% \mathrm{NaCl}$ stress condition, but not always under $0.6 \% \mathrm{NaCl}$ concentration. It was shown significantly negative correlation $(\mathrm{p}<0.5)$ between the $\mathrm{Na}^{+}$content and dry weight of shoot and root under $1.2 \% \mathrm{NaCl}$ stress condition. Also, was founded significantly negative impact $(\mathrm{p}<0.5)$ of $\mathrm{Cl}^{-}$ions on biomass growth and survival rice plants and positive relationship $(\mathrm{p}<0.5)$ among the root dry weight and $\mathrm{K}^{+}, \mathrm{NO}_{3}^{-}$content under the high $\mathrm{NaCl}$ concentration $(1.2 \% \mathrm{NaCl})$. So, in addition to $\mathrm{Na}^{+}$, the contributions of $\mathrm{Cl}^{-}$ to abiotic stresses of rice should not be ignored.
\end{abstract}

Keywords: Salt Stress, Ion Balance, Dry Weight, Adaptation, Rice

\section{Introduction}

Rice is important crops used as the staple food of over half of the world's population and the increase rice grain production is the actual goal for today. One of the severe limitations to increase rice production is considered to soil salinity (Ali et al., 2014). So, current FAO assessment (2015) specifies that globally the area of soil salinity was more than 400 million ha.

As is known, the adaptations plants to extreme environmental factors are manifested at different levels of organization of the organism (Negrao et al., 2011; Usatov et al., 2015). The study of morpho-physiological response to salinity is important with the standpoint of understanding the mechanisms of plant adaptation to stressful influences. The pivot to plant survival under salinity is preserving an ion balance in the cells (Das et al., 2015). For plants, potassium $\left(\mathrm{K}^{+}\right)$and nitrate $\left(\mathrm{NO}_{3}^{-}\right)$ions are essential for the adjustment of osmotic pressure, sustentation of membrane potential, activation of enzymes, stomatal movement, turgor pressure and etc., whereas sodium ions $\left(\mathrm{Na}^{+}\right)$are harmful (Mekawy et al., 2011; Platten et al., 2013). There are some debates about the detrimental effects of chlorine ions $\left(\mathrm{Cl}^{-}\right)$on plant metabolism (Mekawy et al., 2011).

The most studies have focused on the evaluating of rice salt tolerance at germination or seedling stage, because the initial plant resistance influences the final yield (Mardani et al., 2014; Negrao et al., 2011; Hu et al., 2012; Ali et al., 2014). However, assessment of salt tolerance at the germination or seedling stage does not always correlate with that in the later stages of growth (Mass and Grieve 1994; Ferdose et al., 2009; Zeng et al., 2002). In this study, we studied the effects of salt stress on ion balance at vegetative stage of rice.

\section{Materials and Methods}

\section{Plant Materials}

In the present work were used ten rice (Oryza sativa L.) cultivars of the Russian breeding. These genotypes 
were selected based on their agronomic performance and varying of salt tolerance. All the germplasm samples were to subspecies japonica.

\section{Evaluation of Salinity Tolerance}

Rice seeds were surface sterilized by $5.2 \% \mathrm{NaOCl}$ solution for $20 \mathrm{~min}$ and were then rinsed with distilled water. The seeds were soaked in water for $12 \mathrm{~h}$ and placed in special trays with soil (Thomson et al., 2010; Usatov et al., 2015; Xiong and Choong, 2014).

Artificial salinization of the soil, at the rate of $0.6 \%$ and $1.2 \%$ on its dry weight, was performed by adding an appropriate quantity of $\mathrm{NaCl}$. Rice was grown in a growth chamber (Binder, $\mathrm{GmbH}$ ) under the next operated environmental conditions: $72 \%$ relative humidity, $26 \pm 1^{\circ} \mathrm{C}$ and a $14 \mathrm{~h}$ photoperiod. After 35 days, Root Dry Weight (RDW), Shoot Dry Weight (SDW) and total survival percentage of plants were measured. For dry weight measure, rice shoots and roots were desiccated at $75^{\circ} \mathrm{C}$ for three days previous to being weighed (Kumar and Kumar, 2014; Usatov et al., 2015).

\section{Determining Ions Concentrations}

The $\mathrm{Na}^{+}, \mathrm{K}^{+}, \mathrm{Cl}^{-}$and $\mathrm{NO}_{3}{ }^{-}$concentrations in roots and shoots were quantified utilization a capillary electrophoresis system Capel-105M (Lumex, Russia). Dried specimens of plant substance were powdered and treated with $15 \mathrm{~mL}$ deionized water at $100^{\circ} \mathrm{C}$ for $1.5 \mathrm{~h}$ and the extract utilized to set the concentrations of free inorganic ions.

\section{Data Analysis}

The collected data were processed to t-test. Differences were considered statistically significant when $p<0.05$. All data were presented by an average of the four replicates and the standard deviations.

\section{Results}

\section{Evaluation of Salinity Tolerance}

Analysis of the total survival percentage of rice breeding material under salt stress showed different decline in this value depending on the genotype (Table
1). The most negative effect of stress factors on the rice plants survival showed under $1.2 \% \mathrm{NaCl}$ conditions. The highest survival decrease was found in the variety Yuzhanin, compared to the control. The most tolerance lines in this value were K2420-Ostap and K2495-Ostap 89.5 and $100 \%$, respectively. Also, high tolerance lines were K-7256 and Bacchus-Khazar-deviation from control less than $20 \%$.

Under $0.6 \% \mathrm{NaCl}$ stress conditions, the Dry Weight (DW) was not significantly changed in all cultivars. The largest decline root and shoot dry weights were revealed in the variety Boyarin. Under $1.2 \% \mathrm{NaCl}$ stress conditions, the biomass growth was strongly suppressed. The lowest suppression of Shoot Dry Weight (SDW) was shown in the variety Aiceberg, while the largest decline SDW under salt stress $(1.2 \%$ $\mathrm{NaCl}$ ) was found in the variety Yuzhanin. The lowest Root Dry Weight (RDW) decrease was shown in the variety Aiceberg and K2495-Ostap, the largest decrease RDW was revealed in the variety Boyarin.

\section{Ion Accumulation}

The ion contents in shoot and root of the investigated rice cultivars are illustrated on Fig. 1 and 2. From these figures it is seen that with the rising salinity, ion content indexes are able to distinguish genotypes under investigation to greater extent. It was shown that between rice genotypes at vegetative stage there are significant variations of $\mathrm{Na}^{+}, \mathrm{K}^{+}$and $\mathrm{NO}_{3}^{-}$contents, but not $\mathrm{Cl}^{-}$content under control condition. The low salinity treatment $(0.6 \%)$ influenced on the ion balance of rice plants to a lesser degree than high salinity treatments (1.2\%). Under $1.2 \% \mathrm{NaCl}$ stress conditions, the highest increase of $\mathrm{Na}^{+}$content and especially $\mathrm{Cl}^{-}$content were found in shoot of the cultivar Yuzhanin. For this cultivar has also been shown the lowest survival percentage, compared to the control.

Generally, salt treatment strongly stimulated accumulations of $\mathrm{Na}^{+}, \mathrm{Na}^{+} / \mathrm{K}^{+}$ratio, $\mathrm{Cl}^{-}$in shoot and root and salt stress reduced $\mathrm{K}^{+}, \mathrm{NO}_{3}^{-}$contents in both organs under $1.2 \% \mathrm{NaCl}$ stress condition, but not always under $0.6 \% \mathrm{NaCl}$ concentration.

Table 1. The Total Survival percentage of plants (TS), Shoot Dry Weight (SDW) and Root Dry Weight (RDW) of rice under control and salt stress conditions

\begin{tabular}{|c|c|c|c|c|c|c|c|c|c|}
\hline \multirow[b]{2}{*}{ Cultivars } & \multicolumn{3}{|l|}{ Control } & \multicolumn{3}{|c|}{$0.6 \% \mathrm{NaCl}$} & \multicolumn{3}{|c|}{$1.2 \% \mathrm{NaCl}$} \\
\hline & $\mathrm{TS},(\%)$ & SDW, (g) & RDW,(g) & $\mathrm{TS},(\%)$ & SDW, (g) & RDW, (g) & $\mathrm{TS},(\%)$ & SDW, (g) & RDW, (g) \\
\hline Boyarin & $99.0 \pm 0.5$ & $0.34 \pm 0.04$ & $0.17 \pm 0.02$ & $95.0 \pm 3.5$ & $0.18 \pm 0.02^{*}$ & $0.06 \pm 0.001^{*}$ & $60.0 \pm 2.0$ & $0.05 \pm 0.007^{*}$ & $0.02 \pm 0.003^{*}$ \\
\hline Yuzhanin & $98.0 \pm 1.0$ & $0.11 \pm 0.01$ & $0.03 \pm 0.002$ & $45.0 \pm 4.0$ & $0.12 \pm 0.02$ & $0.02 \pm 0.003^{*}$ & $35.0 \pm 3.5$ & $0.02 \pm 0.003^{*}$ & $0.01 \pm 0.003^{*}$ \\
\hline Kuboyar & $100.0 \pm 0$ & $0.17 \pm 0.01$ & $0.12 \pm 0.004$ & $50.0 \pm 2.3$ & $0.16 \pm 0.003$ & $0.07 \pm 0.004^{*}$ & $60.0 \pm 2.2$ & $0.04 \pm 0.003^{*}$ & $0.02 \pm 0.004^{*}$ \\
\hline $\mathrm{K}-7256$ & $90.0 \pm 2.0$ & $0.11 \pm 0.02$ & $0.08 \pm 0.002$ & $72.2 \pm 1.5$ & $0.10 \pm 0.03$ & $0.05 \pm 0.002^{*}$ & $83.3 \pm 4.1$ & $0.05 \pm 0.001^{*}$ & $0.02 \pm 0.003^{*}$ \\
\hline Aiceberg & $100.0 \pm 0.0$ & $0.10 \pm 0.01$ & $0.06 \pm 0.003$ & $75.0 \pm 2.4$ & $0.15 \pm 0.01^{*}$ & $0.05 \pm 0.004$ & $70 \pm 3.0$ & $0.07 \pm 0.002^{*}$ & $0.03 \pm 0.006^{*}$ \\
\hline Bacchus- Donchak & $85.0 \pm 3.0$ & $0.11 \pm 0.02$ & $0.06 \pm 0.003$ & $58.8 \pm 3.3$ & $0.12 \pm 0.02$ & $0.04 \pm 0.001^{*}$ & $64.7 \pm 2.8$ & $0.04 \pm 0.002^{*}$ & $0.01 \pm 0.002^{*}$ \\
\hline Bacchus-Khazar & $95.0 \pm 1.0$ & $0.08 \pm 0.01$ & $0.04 \pm 0.003$ & $73.7 \pm 4.4$ & $0.06 \pm 0.01$ & $0.03 \pm 0.005$ & $84.2 \pm 1.5$ & $0.03 \pm 0.005^{*}$ & $0.02 \pm 0.002^{*}$ \\
\hline Bacchus-Khazar- 9403 & $100.0 \pm 0.0$ & $0.10 \pm 0.01$ & $0.05 \pm 0.002$ & $85.0 \pm 2.5$ & $0.09 \pm 0.009$ & $0.03 \pm 0.002^{*}$ & $60.0 \pm 4.5$ & $0.03 \pm 0.001^{*}$ & $0.02 \pm 0.001^{*}$ \\
\hline K-2420-Ostap & $95.0 \pm 1.5$ & $0.16 \pm 0.03$ & $0.07 \pm 0.004$ & $84.2 \pm 3.0$ & $0.15 \pm 0.03$ & $0.05 \pm 0.005^{*}$ & $89.5 \pm 2.4$ & $0.07 \pm 0.001^{*}$ & $0.03 \pm 0.006^{*}$ \\
\hline K-2495-Ostap & $98.0 \pm 1.0$ & $0.11 \pm 0.01$ & $0.06 \pm 0.002$ & $99.0 \pm 0.5$ & $0.11 \pm 0.02$ & $0.05 \pm 0.005$ & $98.0 \pm 0.5$ & $0.04 \pm 0.002^{*}$ & $0.03 \pm 0.004^{*}$ \\
\hline
\end{tabular}

* Display significant dissimilarity from control at $\mathrm{p}<0.05$ 

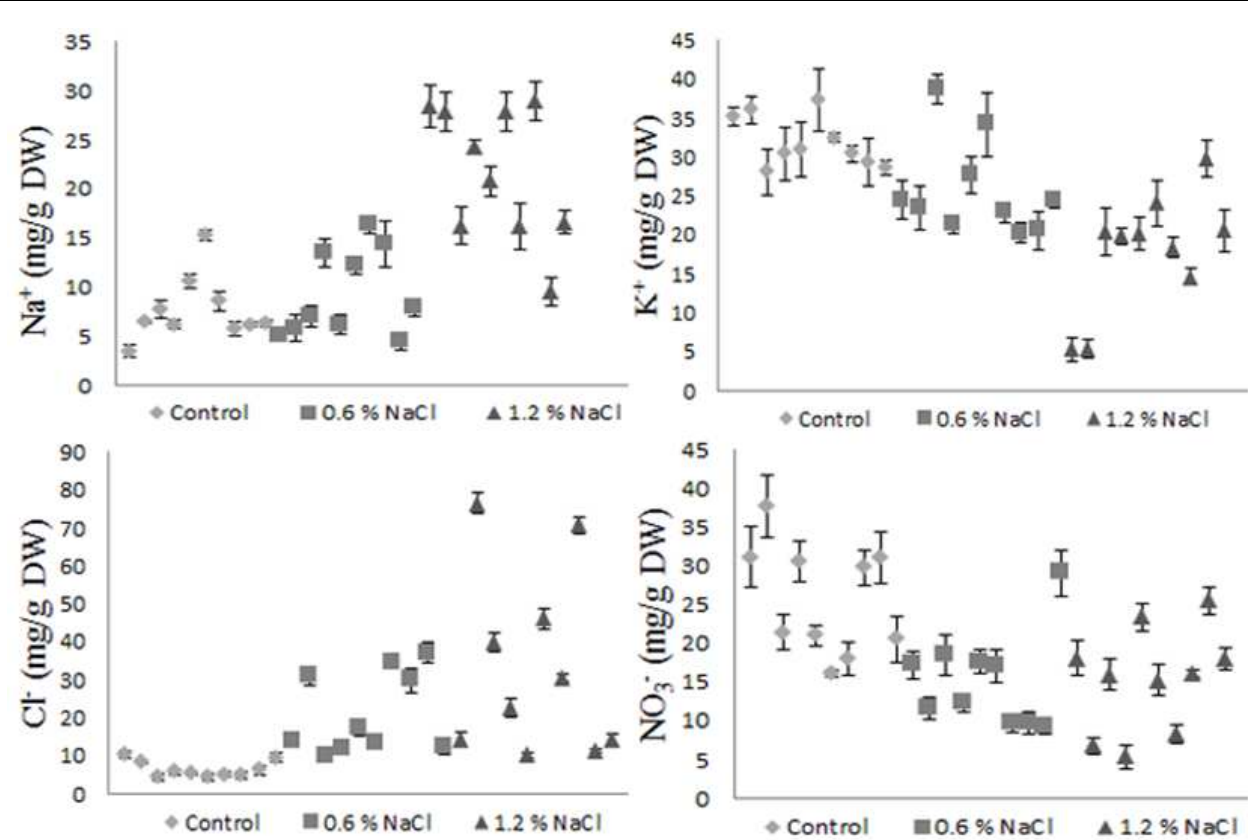

Fig. 1. Ion accumulation in shoots of rice under control, 0.6 and $1.2 \% \mathrm{NaCl}$ conditions
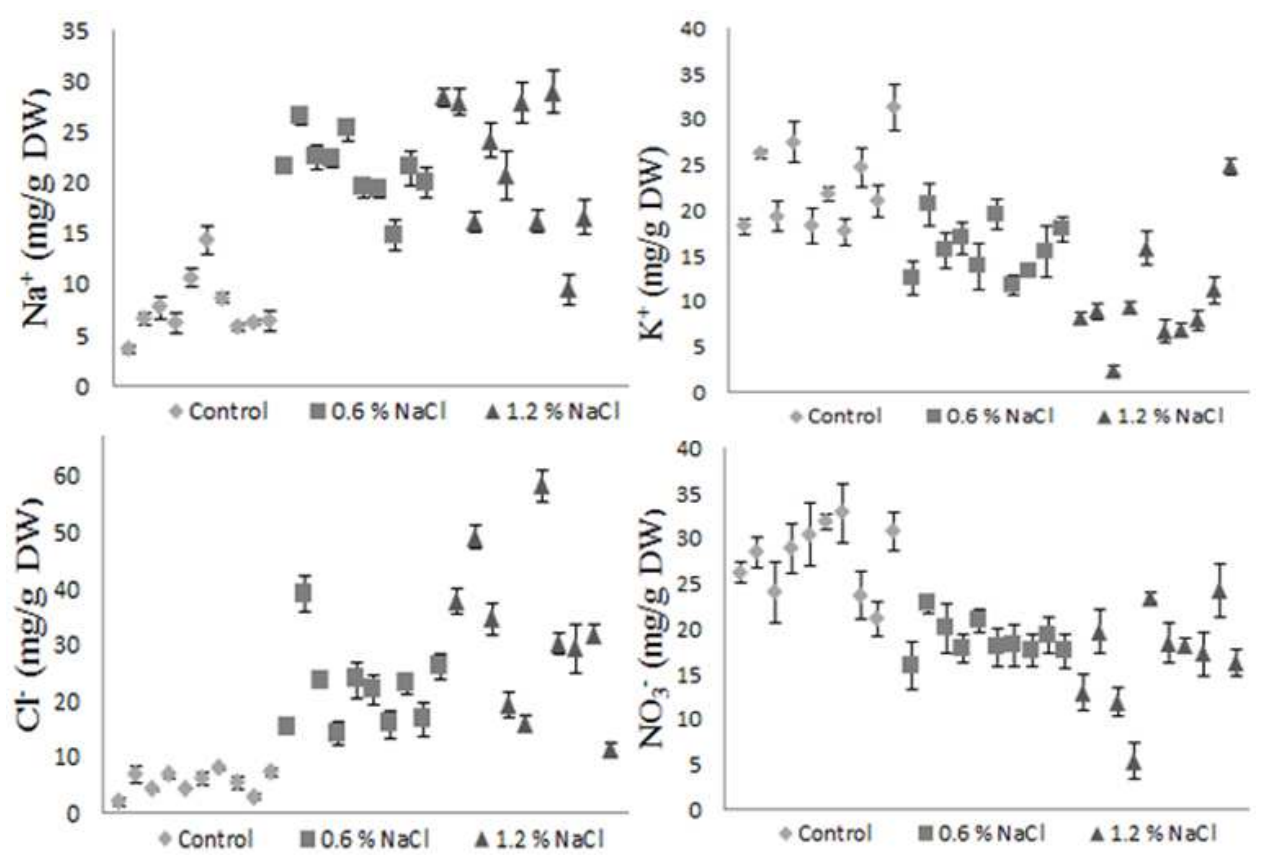

Fig. 2. Ion accumulation in roots of rice under control, 0.6 and $1.2 \% \mathrm{NaCl}$ conditions

\section{Correlation Analysis}

The relationships between the dry weight indices, total survival percentage of plants and ion content at different salinity levels are presented here.

There was a significant negative correlation $(p<0.5)$ between the $\mathrm{Na}^{+}$content and RDW under $1.2 \% \mathrm{NaCl}$ condition, but no significant correlation was revealed under $0.6 \% \mathrm{NaCl}$ and the control conditions (Table 2 and 3). The relationship among SDW and $\mathrm{Na}^{+}$was highly significant both under 0.6 and $1.2 \% \mathrm{NaCl}$ conditions.

The correlations between $\mathrm{Cl}^{-}$content and RDW, SDW were strong negative only under $1.2 \% \mathrm{NaCl}$ concentration and not under $0.6 \% \mathrm{NaCl}$ and the control conditions. The correlations for $\mathrm{NO}_{3}^{-}$and $\mathrm{K}^{+}$were significantly positive only between ions content and RDW under $1.2 \% \mathrm{NaCl}$ condition. 
Table 2. Correlation matrix between the variables at $0.6 \% \mathrm{NaCl}$ conditions

\begin{tabular}{|c|c|c|c|}
\hline \multirow[b]{2}{*}{ Variables } & \multicolumn{3}{|l|}{ Variables } \\
\hline & TS (shoot/root ion content) & SDW & RDW \\
\hline $\mathrm{TS}$ & - & - & - \\
\hline SDW & 0.05 & - & - \\
\hline RDW & 0.27 & $0.94 *$ & - \\
\hline $\mathrm{Na}^{+}$ & $-0.42 /-0.35$ & $-0.83^{*}$ & -0.35 \\
\hline $\mathrm{K}^{+}$ & $-0.48 /-0.51$ & 0.36 & -0.32 \\
\hline $\mathrm{Cl}^{-}$ & $-0.35 /-0.48$ & -0.35 & -0.5 \\
\hline $\mathrm{NO}_{3}^{-}$ & $0.45 /-0.54$ & 0.62 & 0.33 \\
\hline
\end{tabular}

TS- Total Survival percentage of plants; SDW- Shoot Dry Weight; RDW- Root Dry Weight. *Display significant dissimilarity from control at $\mathrm{p}<0.05$

Table 3. Correlation matrix between the variables at $1.2 \% \mathrm{NaCl}$ conditions

\begin{tabular}{|c|c|c|c|}
\hline \multirow[t]{2}{*}{ Variables } & \multicolumn{3}{|l|}{ Variables } \\
\hline & TS (shoot/root ion content) & SDW & RDW \\
\hline TS & - & - & - \\
\hline SDW & 0.53 & - & - \\
\hline RDW & 0.26 & 0.15 & - \\
\hline $\mathrm{Na}^{+}$ & $-0.01 /-0.67 *$ & $-0.85^{*}$ & $-0.67 *$ \\
\hline $\mathrm{K}^{+}$ & $0.65 * / 0.50$ & 0.63 & $0.71 *$ \\
\hline $\mathrm{Cl}^{-}$ & $-0.72 * /-0.68 *$ & $-0.83^{*}$ & $-0.69 *$ \\
\hline $\mathrm{NO}_{3}^{-}$ & $-0.14 / 0.32$ & 0.61 & $0.69^{*}$ \\
\hline
\end{tabular}

TS- Total Survival percentage of plants; SDW- Shoot Dry Weight; RDW- Root Dry Weight. *Display significant dissimilarity from control at $\mathrm{p}<0.05$

The relationship among the total survival percentage of plants and ion concentrations was also examined and there were a fairly strong negative linear association between survival of rice plants and $\mathrm{Cl}^{-}$concentrations in root and shoot, under $1.2 \% \mathrm{NaCl}$ stress condition (Table 3 ).

\section{Discussion}

Rice is highly susceptible to salinity, but the degree of susceptibility differs with varieties (Negrao et al., 2011; Hoang et al., 2015). Accurate phenotyping is important for studying impacts of salinity on ion balance (Wang et al., 2012). Previous studies showed that the salt tolerance of genotypes could be determined by comparing the production of biomass after a sufficiently long period of growth under salinity (Leland et al., 1994). The accumulation of plant biomass is closely related to their productivity and varies considerably depending on the salinity and salt tolerance of variety ( $\mathrm{Hu}$ et al., 2012; Ali et al., 2014; Usatov et al., 2014). Under $1.2 \% \mathrm{NaCl}$ condition the lowest suppression of dry weight was shown in the variety Aiceberg whereas under $0.6 \%$ salt concentration there was a significant stimulation $(50 \%$ of control) of shoot biomass growth of this variety. Also high tolerance to salinity was revealed in the samples K-7256, K-2495-Ostap and K-2420-Ostap.

Cellular ion homeostasis is fundamental in the processes of growth and development of higher plants (Negrao et al., 2011; Senadheera et al., 2009). Salinity stress reasons an unbalance of ion homeostasis in cells, leading to ion toxicity (Ferdose et al., 2009; Mekawy et al., 2011; Cotsaftis et al., 2012). At the initial stages of growth, the ability to maintain a high $\mathrm{K}^{+} / \mathrm{Na}^{+}$ratio in roots or shoots is regarded an indicator of probable salt tolerance in rice (Mardani et al., 2014; Wang et al., 2012). A similar result was observed at vegetative stage in our research. In this study there were significantly negative correlations $(\mathrm{p}<0.5)$ between the $\mathrm{Na}^{+}$content and $\mathrm{DW}$ of root and shoot under $1.2 \% \mathrm{NaCl}$ condition and under $0.6 \% \mathrm{NaCl}$ condition a significant negative correlation was identified between the $\mathrm{Na}^{+}$content and shoot DW. Also, we revealed a strong negative impact of $\mathrm{Cl}^{-}$ions on biomass growth and survival rice plants under the high $\mathrm{NaCl}$ concentration $(1.2 \% \mathrm{NaCl})$. Under salt stress condition, plants have $\mathrm{K}^{+}$and $\mathrm{NO}_{3}{ }^{-}$ deficiencies due to the competitive inhibition of their uptake by $\mathrm{Na}^{+}$and $\mathrm{Cl}^{-}$(Mekawy et al., 2011; Negrao et al., 2011). In our study were revealed significantly positive relationships among the root $\mathrm{DW}$ and $\mathrm{K}^{+}, \mathrm{NO}_{3}^{-}$content, but not between $\mathrm{K}^{+}, \mathrm{NO}_{3}{ }^{-}$and shoot $\mathrm{DW}$ or survival of rice plants. In this case the capacity to maintain the transport and stockpiling of $\mathrm{K}^{+}$and $\mathrm{NO}_{3}^{-}$in root is important salt-tolerant trait at vegetative stage. Thus, salinity stress at vegetative stage of rice leads to serious disruption of ion homeostasis.

\section{Conclusion}

Laboratory examination of the rice cultivars showed that shoot dry weight, root dry weight and total survival 
percentage of plants at vegetative stage declined under salinity. The minimal reduction of growth under salt stress was revealed in the variety Aiceberg and in the lines K7256-Ostap, K2420-Ostap and Bacchus-Khazar, while the largest decline shoot dry weight, root dry weight and total survival percentage of rice plants was found in the varieties Boyarin and Yuzhanin. It was shown that the salt concentration for the treatment is especially significant for efficient assessment of the relationship between ion accumulation and rice salt tolerance. Salt treatment strongly stimulated accumulations of $\mathrm{Na}^{+}, \mathrm{Na}^{+} / \mathrm{K}^{+}$ratio, $\mathrm{Cl}^{-}$in shoot and root and reduced $\mathrm{K}^{+}, \mathrm{NO}_{3}^{-}$contents in both organs under $1.2 \% \mathrm{NaCl}$ stress conditions, but not always under $0.6 \%$ $\mathrm{NaCl}$ concentration. The studies of ion ratio revealed a valid negative correlation $(p<0.5)$ between the $\mathrm{Na}^{+}$ content and DW of root and shoot under $1.2 \% \mathrm{NaCl}$ condition. Also, we founded significantly negative impact of $\mathrm{Cl}^{-}$ions on biomass growth and survival rice plants and positive relationship among the root DW and $\mathrm{K}^{+}, \mathrm{NO}_{3}^{-}$content under the high $\mathrm{NaCl}$ concentration $(1.2 \% \mathrm{NaCl})$. Therefore in addition to $\mathrm{Na}^{+}$, the contributions of $\mathrm{Cl}^{-}$to abiotic stresses of rice should not be ignored. Thus, salinity stress at vegetative stage of rice initiates significant alterations to many physiological processes of plant cells, including ion homeostasis, which all may cause to yield reduction.

\section{Acknowledgement}

The authors acknowledge the Ministry of Education and Science of the Russian Federation for financial support under the research project no. 40.91.2014/K.

\section{Funding Information}

The founders of this research were Russian Ministry of Education and Science, project no. 40.91.2014/K.

\section{Author's Contributions}

All authors equally contributed in this work.

\section{Ethics}

The authors declare that this article is original and corresponds to the ethical norms specified by the OnLine Journal of Biological Sciences.

\section{References}

Ali, M.N., L. Yeasmin, S. Gantait, R. Goswami and S. Chakraborty, 2014. Screening of rice landraces for salinity tolerance at seedling stage through morphological and molecular markers. Physiol. Mol. Biol. Plants, 20: 411-423.

DOI: $10.1007 / \mathrm{s} 12298-014-0250-6$
Cotsaftis, O., D. Plett, N. Shirley, M. Tester and M. Hrmova, 2012. A two-staged model of $\mathrm{Na}^{+}$ exclusion in rice explained by 3D modeling of HKT transporters and alternative splicing. PLoS ONE, 7: e39865-e39865. DOI: 10.1371/journal.pone.0039865

Das, P., K.K. Nutan, S.L. Singla-Pareek and A. Pareek, 2015. Understanding salinity responses and adopting "omics-based" approaches to generate salinity tolerant cultivars of rice. Frontiers Plant Sci., 6: 712-712. DOI: 10.3389/fpls.2015.00712

Ferdose, J., M. Kawasaki, M. Taniguchi and H. Miyake, 2009. Differential sensitivity of rice cultivars to salinity and its relation to ion accumulation and root tip structure. Plant Prod Sci., 12: 453-461. DOI: $10.1626 /$ pps. 12.453

Hoang, T.M.L., L. Moghaddam, B. Williams, H. Khanna and J. Dale et al., 2015. Development of salinity tolerance in rice by constitutive-overexpression of genes involved in the regulation of programmed cell death. Frontiers Plant Sci., 6: 175-175.

DOI: $10.3389 /$ fpls.2015.00175

Hu, S., H. Tao, Q. Qian and L. Guo, 2012. Genetics and molecular breeding for salt-tolerance in rice. Rice Genom. Genet., 3: 39-38. DOI: $10.5376 /$ rgg.2012.03.0007

Kumar, D. and R.V. Kumar, 2014. Efficacy of bio-foliar spray on growth and biochemical parameters of different mulberry varieties. OnLine J. Biol. Sci., 14: 64-69. DOI: 10.3844/ojbsci.2014.64.69

Leland, E.F., M.G. Catherine, V.M. Eugene and M.L. Scott, 1994. Time of salt stress affects growth and yield components of irrigated wheat. Agron. J., 86: 100-107. DOI: 10.2134/agronj1994.00021962008600010019x

Mardani, Z., B. Rabiei, H. Sabouri and A. Sabouri, 2014. Identification of molecular markers linked to salttolerant genes at germination stage of rice. Plant Breed., 133: 196-202. DOI: 10.1111/pbr.12136

Mass, E.V. and C.M. Grieve, 1994. Tiller development in salt-stressed wheat. Crop Sci., 34: 1594-1603. DOI: $10.2135 /$ cropsci1994.0011183X003400060032x

Mekawy, A.M., D.V. Assaha, H. Yahagi, Y. Tada and A. Ueda et al., 2011. Growth, physiological adaptation and gene expression analysis of two Egyptian rice cultivars under salt stress. Plant Physiol. Biochem., 1 87: 17-25. DOI: $10.1016 /$ j.plaphy.2014.12.007

Negrao, S., B. Courtois, N. Ahmadi, I. Abreu and N. Saibo et al., 2011. Recent updates on salinity stress in rice: From physiological to molecular responses. Critical Rev. Plant Sci., 30: 329-377. DOI: 10.1080/07352689.2011.587725

Platten, J.D., J.A. Egdane and A.M. Ismail, 2013. Salinity tolerance, $\mathrm{Na}^{+}$exclusion and allele mining of HKT1;5 in Oryza sativa and O. glaberrima: Many sources, many genes, one mechanism. BMC Plant Biol., 13: 32-32. DOI: 10.1186/1471-2229-13-32 
Senadheera, P., R.K. Singh and F.J.M. Maathuis, 2009. Differentially expressed membrane transporters in rice roots may contribute to cultivar dependent salt tolerance. J. Exp. Botany, 60: 2553-2563. DOI: $10.1093 / \mathrm{jxb} / \mathrm{erp} 099$

Thomson, M.J., M. Ocampo, J. Egdane, M.A. Rahman and A.G. Sajise et al., 2010. Characterizing the saltol quantitative trait locus for salinity tolerance in rice. Rice, 3: 148-160. DOI: $10.1007 / \mathrm{s} 12284-010-9053-8$

Usatov, A.V., A.V. Alabushev, P.I. Kostylev, K.V. Azarin and M.S. Makarenko et al., 2015. Introgression the SalTol QTL into the elite rice variety of Russia by marker-assisted selection. Am. J. Agric. Biol. Sci., 10: 165-169. DOI: 10.3844/ajabssp.2015.165.169

Usatov, A.V., A.I. Klimenko, K.V. Azarin, O.F. Gorbachenko and N.V. Markin et al., 2014. DNA-markers of sunflower resistance to the downy mildew (Plasmopara halstedii). Am. J. Biochem. Biotech., 10: 125-129.

DOI: 10.3844/ajbbsp.2014.125.129
Wang, Z., Z. Chen, J. Cheng, Y. Lai and J. Wang et al., 2012. QTL analysis of $\mathrm{Na}+$ and $\mathrm{K}+$ concentrations in roots and shoots under different levels of $\mathrm{NaCl}$ stress in rice (Oryza sativa L.). PLoS One, 7: e51202- e51202.

DOI: 10.1371 /journal.pone.0051202

Xiong, Z. and C.W. Choong, 2014. Optimum micronutrient level for Phalaenopsis deliciosa orchid seedling In vitro growth. Online J. Biol. Sci., 14: 240-244. DOI: 10.3844/ojbsci.2014.240.247

Zeng, L., M.C. Shannon and C.M. Grieve, 2002. Evaluation of salt tolerance in rice genotypes by multiple agronomic parameters. Euphytica, 127: 235-245. DOI: 10.1023/A:1020262932277 